A Camera in the Garden of Eden 
A Camera in 


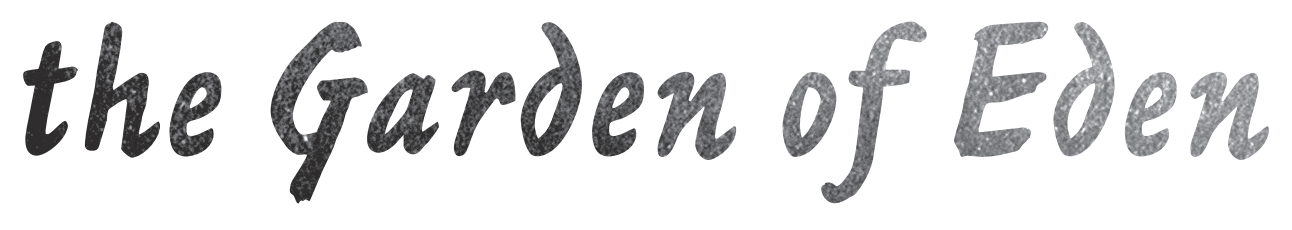

THE SELF-FORGING OF A BANANA REPUBLIC

\section{Kevin Coleman}


Copyright (c) 2016 by the University of Texas Press

All rights reserved

Printed in the United States of America

First edition, 2016

Requests for permission to reproduce material

from this work should be sent to:

Permissions

University of Texas Press

P.O. Box 7819

Austin, TX 78713-7819

www.utexas.edu/utpress/about/bpermission.html

The paper used in this book meets the minimum requirements of ANSI/NISO Z39.48-1992 (R1997) (Permanence of Paper).@

Coleman, Kevin P., author.

A camera in the garden of Eden : the self-forging of a banana republic / by Kevin Coleman. - First edition.

pages $\mathrm{cm}$

Includes bibliographical references and index.

ISBN 978-1-4773-0854-7 (cloth : alk. paper)

ISBN 978-1-4773-0855-4 (pbk. : alk. paper)

ISBN 978-1-4773-0857-8 (library e-book)

ISBN 978-1-4773-0856-1 (non-library e-book)

1. Photography-Social aspects. 2. Plantation workers-

Honduras-Social conditions. 3. Banana trade-Honduras-

History. 4. Visual communication-Social aspects. 5. Honduras-

History. 6. Photography-Honduras. I. Title.

TR183.C66 2016

$770.97283-\mathrm{dc} 23$

2015024075

doi:10.756o/308547 
For my mom and dad, and

Hema and Saagari 
Taken and retaken by sea rovers, by adverse powers and by sudden uprising of rebellious factions, the historic 300 miles of adventurous coast has scarcely known for hundreds of years whom rightly to call its master. ... The guns of the rovers are silenced; but the tintype man, the enlarged photograph brigand, the kodaking tourist and the scouts of the gentle brigade of fakirs have found it out, and carry on the work.

O. Henry, Cabbages and Kings 